\title{
VARIABILITY OF VESSEL CHARACTERISTICS IN THE XYLEM OF ILEX PARAGUARIENSIS (MATÉ-TREE) FROM SOUTH BRAZIL
}

\author{
Oliver Dünisch ${ }^{1,2}$, Carlos Bruno Reissmann ${ }^{2}$ \& Afonso Oliszeski ${ }^{3}$
}

\begin{abstract}
SUMMARY
In this study the wood anatomy of two leaf-morphotypes ("Yellow" and "Grey") of Ilex paraguariensis St. Hil. (Aquifoliaceae) from South Brazil was compared with special attention to vessel attributes and a possible relationship of leaf morphology and wood structure. Sampling was carried out in a 15-year-old plantation in the state of Paraná, South Brazil. The anatomy of the juvenile and mature wood of five male and five female plants of each morphotype was investigated by light microscopy. In all plants the increment and the proportion of vessels decreased from pith to cambium, while vessel element length increased. Plants of the morphotype "Grey" had shorter vessel members (157-382 $\mu \mathrm{m})$ and a lower number of bars per perforation plate (14-15) compared to the plants of the morphotype "Yellow" (vessel member length: 304-567 $\mu \mathrm{m}$, bars: 22-24). No significant differences were found between the wood of male and female plants.
\end{abstract}

Key words: Leaf morphology, wood formation, juvenile wood, Ilex paraguariensis St. Hil.

\section{INTRODUCTION}

Maté-tea produced from leaves and young branches of Ilex paraguariensis St. Hil. is an important non-wood forest product in South Brazil as well as in parts of Argentina and Paraguay. Ilex paraguariensis is naturally distributed between $22^{\circ}$ and $30^{\circ}$ south latitude and between $48^{\circ}$ and $56^{\circ}$ west longitude (Oliveira \& Rotta 1995). The maté-tree prefers altitudes between 400 and $1800 \mathrm{~m}$ above sea level with an annual precipitation between 1100 and $2300 \mathrm{~mm}$ (Carvalho 1994). The leaves of Ilex paraguariensis show a high morphological and anatomical variability and at least two native morphotypes named "Yellow" and "Grey" have been recognized in Brazil (Coelho et al. 2002). Scherer et al. (2002) showed that the chemical composition of the leaves of Ilex paraguariensis also varies strongly between individual plants. Although there are some attempts to classify plants of the genus Ilex, and in particular plants of the species Ilex paraguariensis according to their morphological (Loesener 1942) and chemical (Martinez et al. 1997; Valduga et al. 1997; Scherer et al. 2002) characteristics, the knowl-

1) Institute of Applied Botany, University of Hamburg, Ohnhorststr. 18, D-22609 Hamburg, Germany [E-mail: oliver.duenisch@iangbot.uni-hamburg.de].

2) Departamento de Solos e Engenharia Agricola, Universidade Federal do Paraná, Rua dos Funcionarios 1540, 80035-050 Curitiba-PR, Brazil.

3) Fazenda Vila Nova, Cx. Postal 11, 84460-000 Ivai-PR, Brazil. 
edge about the relationship between genetic factors and the plant phenotype is still restricted. In addition the relationship between the phenotype, the ecology, and the properties of the maté is not completely understood, although this information is needed for the selection of seed provenances and the improvement of the properties of the product (maté).

In most recent studies characteristics of the leaves were selected to divide the genus Ilex into sections and to identify morphotypes within the species Ilex paraguariensis, respectively. Although studies by Baas (1973) and Richter and Dallwitz (2000) showed that the anatomy of the xylem of Ilex paraguariensis is very variable, no information on the relationship between the characteristics of the leaves and the wood structure is available.

Investigations of Britez et al. (1997) indicate a relationship between the sex of the plant and the ecological behaviour of Ilex paraguariensis, but information on the wood anatomy of male and female plants is missing. Most of the descriptions of the wood anatomy of Ilex paraguariensis are based on investigations carried out with old plants or experimental plants of unknown age or sex. The structure of juvenile wood shows significant differences compared to mature wood (Brazier 1985; Zobel 1985; Zobel \& Sprague 1998) indicating the need to select trees of a defined age for the comparison of the wood anatomy of plant individuals.

Therefore in this study the wood anatomy of two morphotypes of Ilex paraguariensis (Aquifoliaceae) from South Brazil was compared with special attention to vessel attributes and a possible relationship between leaf morphology, the sex of the plant, tree age, and wood structure.

\section{MATERIAL AND METHODS}

\section{Study sites and tree selection}

For the study a 15-year-old plantation of Ilex paraguariensis St. Hil. (1245 plants) was selected. The study site is located at the Fazenda Bitumirim in the state of Paraná, Brazil $\left(25^{\circ} 15^{\prime} \mathrm{S}, 50^{\circ} 45^{\prime} \mathrm{W}, 870 \mathrm{~m}\right.$ above sea level). The annual precipitation is about $1,570 \mathrm{~mm}$ and the mean air temperature is $19.1^{\circ} \mathrm{C}$. July and August are the driest and coldest months of the year with a monthly precipitation of about 70 and $100 \mathrm{~mm}$ and a mean air temperature of about $15^{\circ} \mathrm{C}$, respectively. The soil is an acid oxisol ("Latossolo Vermelho Escuro Álico", EMBRAPA-SNLS 1984) with a low cation exchange capacity.

For the study two morphotypes of Ilex paraguariensis were selected, which are considered to be native in that region. The leaves of the morphotype "Yellow" have a yellow-green colour, while the leaves of the morphotype "Grey" are grey-green (for a detailed description of the leaf morphology of the two morphotypes see Reissmann et al. 2003). Five male and five female plants of each morphotype were selected, which were not used for the production of maté (seed trees, tree selected for the conservation of native gene resources) in order to avoid an impact of the repeated cutting of the twigs for maté harvest on wood formation of the plants. From all 20 plants (5 (plants) $\times$ $2(\operatorname{sex}) \times 2$ (morphotypes) $)$ stem discs were sampled at breast height $(1.3 \mathrm{~m})$. The breast height diameter of the 15-year-old plants varied between 4.38 and $8.72 \mathrm{~cm}$ (Table 1). 
Table 1. Characteristics of the plants selected at the study site "Bitumirim", state of Paraná, Brazil $\left(25^{\circ} 15^{\prime} \mathrm{S}, 50^{\circ} 45^{\prime} \mathrm{W}\right)$. BHD = breast height diameter $(1.3 \mathrm{~m})$.

\begin{tabular}{rllcc}
\hline Tree No. & Morphotype & Sex & Tree age (years) & BHD (cm) \\
\hline 1 & "Yellow" & Male & 15 & 6.32 \\
2 & "Yellow" & Male & 15 & 5.49 \\
3 & "Yellow" & Male & 15 & 5.73 \\
4 & "Yellow" & Male & 15 & 7.25 \\
5 & "Yellow" & Male & 15 & 6.32 \\
6 & "Yellow" & Female & 15 & 4.38 \\
7 & "Yellow" & Female & 15 & 5.79 \\
8 & "Yellow" & Female & 15 & 6.04 \\
9 & "Yellow" & Female & 15 & 5.76 \\
10 & "Yellow" & Female & 15 & 5.91 \\
11 & "Grey" & Male & 15 & 6.09 \\
12 & "Grey" & Male & 15 & 8.72 \\
13 & "Grey" & Male & 15 & 7.02 \\
14 & "Grey" & Male & 15 & 5.33 \\
15 & "Grey" & Male & 15 & 5.48 \\
16 & "Grey" & Female & 15 & 6.04 \\
17 & "Grey" & Female & 15 & 5.18 \\
18 & "Grey" & Female & 15 & 6.32 \\
19 & "Grey" & Female & 15 & 6.09 \\
20 & "Grey" & Female & 15 & 7.01 \\
\hline
\end{tabular}

\section{Microscopical characteristics and width of increment zones}

The width of the increment zones was measured on the discs on the north, south, east and west radius with an eye piece micrometer. From all samples microtome sections (Reichert, Austria; section thickness: $15 \mu \mathrm{m}$ ) were prepared from the pith to the cambium in the three standard anatomical directions. The sections were stained with safranine/ astrablue, Lugol's solution, and sudan III/IV (Romeis 1968).

The cross sections were used to determine the percentage of cell type and the radial and tangential diameter of the vessels. The percentage of cell type was obtained by means of an integration ocular lens (Leucodiff: Höster \& Spring 1971). For the quantification of the percentage of cell type 400 spots each per increment zone were analysed. The diameter of the vessels was measured directly in the microscope (Axioskop MC 80 Zeiss, Germany) with an eye piece micrometer (240 measurements per increment zone).

The number of bars per vessel perforation plate was counted in the radial sections (Fig. 1b, 80 measurements per mm radius, 4 radii per disc). The length of the vessel members was determined after maceration (Jeffrey solution) of small samples (representing approx. $2 \mathrm{~mm}$ of the stem radius) prepared along the 4 radii of the discs. The length of 60 vessel members was measured in each fraction by means of an image analyzer (SigmaScanPro). 

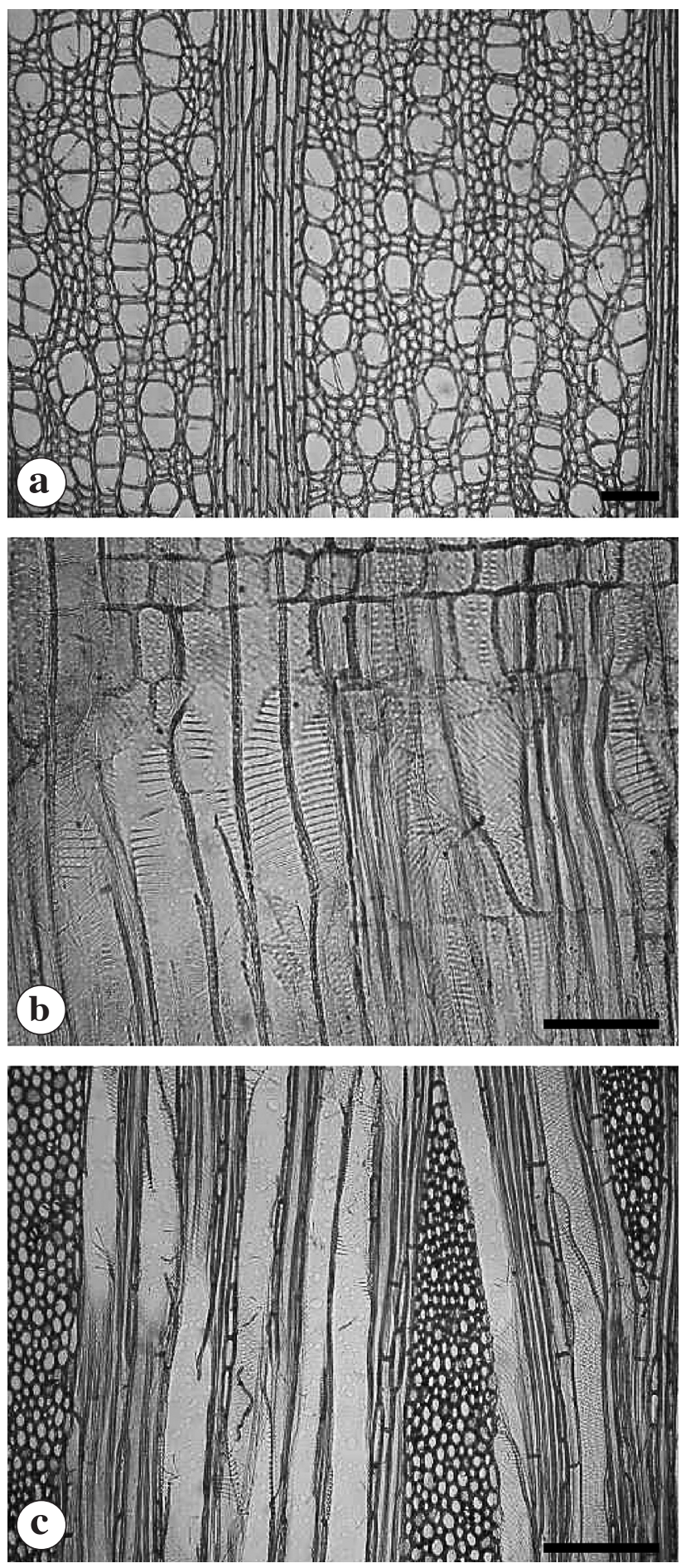

Fig. 1. Xylem of Ilex paraguariensis (tree no. 1):

a: cross section

b: radial section

c: tangential section

Scale bars $=100 \mu \mathrm{m}$. 


\section{Statistical analysis}

The mean value and the standard deviation of each parameter were calculated. The significance of differences between morphotypes, male and female plants, and juvenile and adult plants was assessed by ANOVA at $p \leq 0.05$ by Fisher's $F$-test. In order to identify age trends in wood anatomical characteristics, linear and logarithmic regressions were calculated for each parameter. Significant relationships between age and the anatomical parameters were used to define to a certain level the juvenile and the adult phase of wood formation. If the increase of the regression curve between the tree age and the anatomical parameter varied between -0.1 and +0.1 this parameter was considered to be characteristic for mature wood.

\section{RESULTS}

\section{Anatomical characteristics of the xylem of Ilex paraguariensis}

The primary xylem of all samples was intact and a high portion of the parenchyma cells contained dark staining compounds. Particularly a high content of such compounds was found in the region of the leaf traces and in the transition zone from primary to secondary xylem.

In the secondary xylem of all plants increment zones were present. In 17 out of the 20 experimental plants the number of increment zones was in agreement with the age of the trees, indicating that the formation of increment zones in the xylem of these plants was annual. (Table 1). No significant differences of the percentile composition of vessels $(25 \pm 4 \%)$, fibre tracheids $(43 \pm 5 \%)$, axial $(11 \pm 3 \%)$ and ray parenchyma $(21 \pm 4 \%)$ were found between the two morphotypes and between male and female plants. The distribution of the vessels within the xylem of the samples was diffuse (Fig. 1a). The perforation plates of the vessels were scalariform (Fig. 1b). The fibre tracheids were thin-walled. The apotracheal axial parenchyma was diffuse in the xylem of all samples. The rays of all samples showed a high variability in terms of size and anatomical structure. The mean height of the rays was $473 \pm 126 \mu \mathrm{m}$. Unseriate rays were composed exclusively of upright cells, while multiseriate rays (width 2-17 cells) were composed of procumbent central cells and square to upright marginal cells. In procumbent and upright cells dark staining compounds and crystals of Ca-oxalate were present (chemical structure of the dark staining compounds was not identified, Fig. 1c).

\section{Influence of the tree age and the sex on the vessel characteristics of the morphotypes} "Yellow" and "Grey" of Ilex paraguariensis

In all plants studied the transition from juvenile to adult growth was expressed in terms of mean annual increment, vessel portion, and vessel member length. A strong decrease of annual increment and vessel portion was observed within the first 2 to 3 years of life of the plants (representing the xylem 0-6 mm distant from the pith), while later the decrease was more moderate (Table 2, Fig. 2). In contrast the length of the vessel members increased with increasing tree age (Table 2, Fig. 3). This indicates that to a certain level the transition from juvenile to mature wood occurred in the plants after 2 to 3 years. Within the 15 -year-old plants no age trend was found in the diameter of the vessels and in the number of bars per perforation plate. 
Table 2. Annual increment (mm), vessel portion (\%), vessel member length $(\mu \mathrm{m})$, vessel diameter $(\mu \mathrm{m})$, and number of vessel bars per perforation plate of male and female plants of the morphotypes "Yellow" and "Grey" of Ilex paraguariensis. Mean value \pm standard deviation. Values followed by different letters differ significantly at $\mathrm{p}<0.05$ (Fisher's $F$-test).

\begin{tabular}{lcccc}
\hline Parameter & \multicolumn{2}{c}{ Morphotype "Yellow" } & \multicolumn{2}{c}{ Morphotype "Grey" } \\
\cline { 2 - 5 } & Male & Female & Male & Female \\
\hline Annual increment juvenile growth $(\mathrm{mm})$ & $2.49 \pm 0.55^{\mathrm{a}}$ & $2.73 \pm 0.49^{\mathrm{a}}$ & $4.40 \pm 0.78^{\mathrm{c}}$ & $3.81 \pm 0.57^{\mathrm{c}}$ \\
Annual incement adult rowth $(\mathrm{mm})$ & $1.84 \pm 0.32^{\mathrm{b}}$ & $1.61 \pm 0.32^{\mathrm{b}}$ & $1.52 \pm 0.36^{\mathrm{b}}$ & $1.53 \pm 0.24^{\mathrm{b}}$ \\
& $29 \pm 3^{\mathrm{a}}$ & $28 \pm 5^{\mathrm{a}}$ & $27 \pm 4^{\mathrm{a}}$ & $28 \pm 5^{\mathrm{a}}$ \\
Vessel portion juvenile growth $(\%)$ & $23 \pm 3^{\mathrm{b}}$ & $20 \pm 4^{\mathrm{b}}$ & $18 \pm 4^{\mathrm{b}}$ & $21 \pm 3^{\mathrm{b}}$ \\
Vessel portion adult growth $(\%)$ & & & & \\
& & & & \\
Vessel member length juvenile growth $(\mu \mathrm{m})$ & $359 \pm 73^{\mathrm{a}}$ & $304 \pm 103^{\mathrm{a}}$ & $157 \pm 58^{\mathrm{c}}$ & $218 \pm 93^{\mathrm{c}}$ \\
Vessel member length adult growth $(\mu \mathrm{m})$ & $567 \pm 151^{\mathrm{b}}$ & $519 \pm 119^{\mathrm{b}}$ & $341 \pm 81^{\mathrm{a}}$ & $382 \pm 118^{\mathrm{a}}$ \\
& $50 \pm 7^{\mathrm{a}}$ & $45 \pm 5^{\mathrm{a}}$ & $50 \pm 11^{\mathrm{a}}$ & $43 \pm 7^{\mathrm{a}}$ \\
Vessel diameter $(\mu \mathrm{m})$ & $22 \pm 3^{\mathrm{a}}$ & $24 \pm 2^{\mathrm{a}}$ & $15 \pm 2^{\mathrm{b}}$ & $14 \pm 2^{\mathrm{b}}$ \\
\hline
\end{tabular}

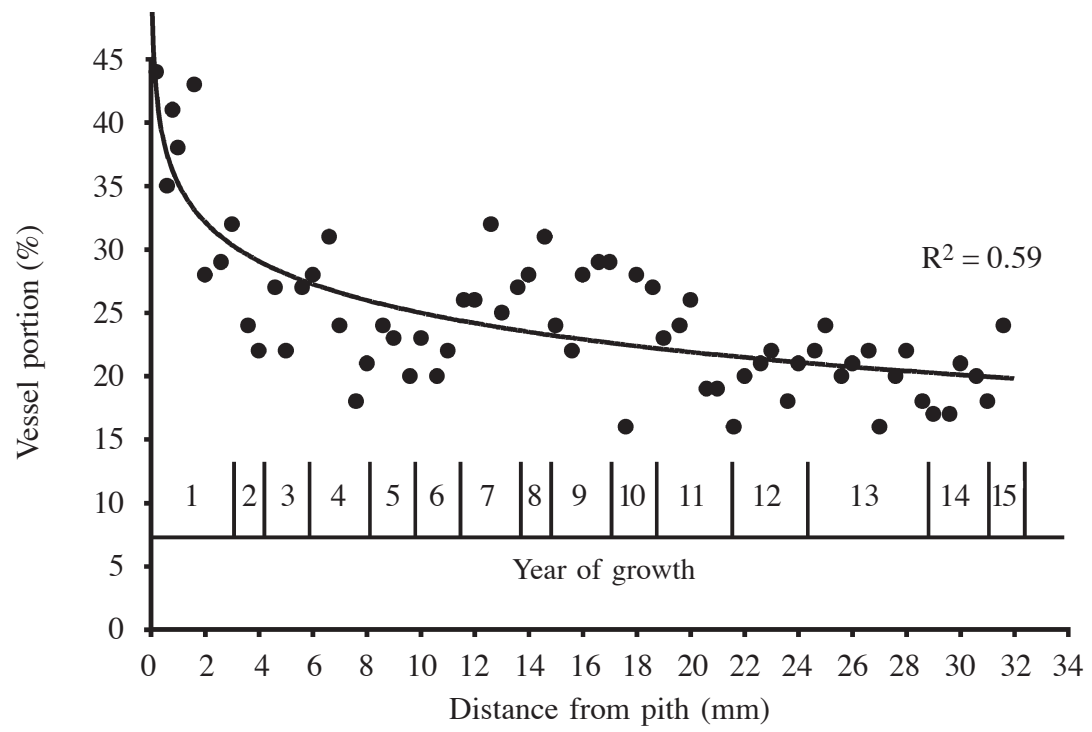

Fig. 2. Vessel portion (\%) from the pith to the cambium in the xylem of 15-year-old Ilex paraguariensis (tree no. 1).

Neither in juvenile nor in the mature wood significant differences in growth and vessel characteristics were found between the male and the female plants (Table 2). During the juvenile phase of growth the annual increment of the plants of the morphotype "Grey" exceeded the annual increment of the plants of the morphotype "Yellow". In contrast, in adult trees no differences in increment were found between plants of the two morpho- 


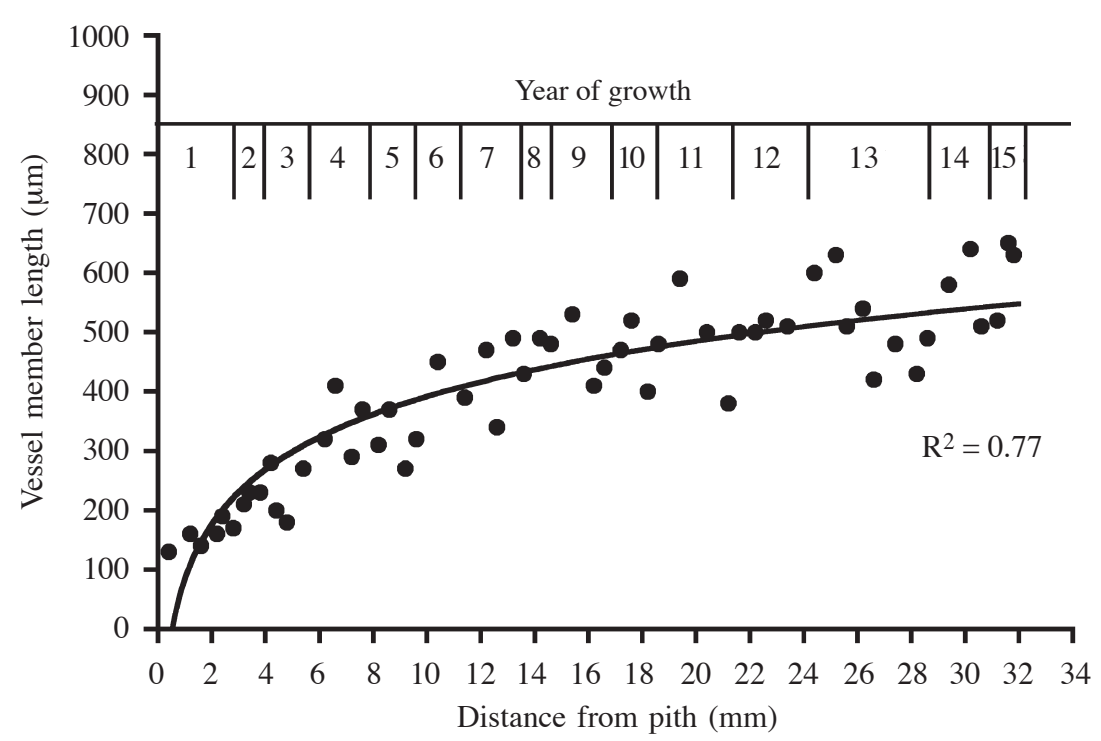

Fig. 3. Vessel member length $(\mu \mathrm{m})$ from the pith to the cambium in the xylem of 15-year-old Ilex paraguariensis (tree no. 1).

types. In the xylem of the morphotype "Yellow" the mean length of the vessel members varied between $304 \mu \mathrm{m}$ (juvenile wood) and $567 \mu \mathrm{m}$ (mature wood), while in the xylem of the morphotype "Grey" the mean length of the vessel members was only $157 \mu \mathrm{m}$ (juvenile wood) to $382 \mu \mathrm{m}$ (mature wood). Beside the reduced length of the vessel members, a lower number of bars per perforation plate was apparent in plants of the morphotype "Grey" compared to plants of the morphotype "Yellow".

\section{DISCUSSION}

For the study of the variability of vessel characteristics in the xylem of Ilex paraguariensis plants from two leaf-morphotypes ("Yellow"and "Grey") were selected. Investigations of Reissmann et al. (1999) and inheritance studies of Scherer et al. (2002) indicate that the species can be divided into at least eight groups. Consequently the selected plants did not represent the entire variability of wood anatomical characteristics, which can be expected within the species. Therefore the investigation has to be considered to be a case study on the relationship between leaf characteristics and wood anatomical features of two phenotypes, which are well recognized as distinct varieties for maté production.

The anatomical characteristics of Ilex paraguariensis found in our study correspond to results obtained for old-growth of Ilex paraguariensis published by Baas (1973, 1975) and Richter and Dallwitz (2000). For Ilex paraguariensis the transition from juvenile to mature wood was not yet described, although investigations of Baas (1973) indicated that juvenile wood formation in species of Ilex is restricted to the innermost 
millimetres of the stem. In agreement with the results of this study the transition from juvenile wood to mature wood formation to a certain level occurred after two to three years of growth, although there was still a tendency for decreasing vessel portion and increasing vessel member length with increasing age in older plants. During the phase of juvenile wood formation a higher increment and a higher portion of vessels were found than during the phase of adult wood formation, while the length of the vessel members was reduced. In contrast to observations from Ohbayashi and Shiokura (1989) and Zobel and Jett (1995) on other tree species, the diameter of the vessels did not increase from the juvenile to the adult phase of growth in Ilex paraguariensis. In addition the diameter of the vessels showed a very low variability indicating that, in contrast to observations of Sass and Eckstein (1995) on Fagus silvatica, the vessel diameter in Ilex paraguariensis is not strongly affected by tree age and exogenous factors.

In plants grown in the same plantation, during the juvenile phase of growth as well as during the adult phase of growth the vessel member length and the number of vessel bars per perforation plate was lower in the xylem of the morphotype "Grey" than in the xylem of the morphotype "Yellow". This indicates that the differences in the vessel characteristics between the two leaf morphotypes are probably due to genetic differences of the plants. In agreement with this result Leal et al. (2003) also found a significant influence of genetic factors on the vessel characteristics of 17 clones of Eucalyptus globulus. Although ecological studies of Britez et al. (1997) showed that male and female plants of Ilex paraguariensis to a certain extend respond in a different manner to exogenous input, our results gave no evidence for a link between the sex of the plants and their wood anatomical characteristics. This shows that further studies on the gene expression in Ilex paraguariensis are needed to understand the formation of varieties within this species (Dinwoodie 1963; Zampier 2001).

On the other hand, in ecological studies vessel characteristics of higher plants are predominately discussed in relation to climatic factors. Investigations of Baas (1973) showed that within the genus Ilex the vessel element length and the number of bars decreased with increasing distance from the equator and increasing altitude. In agreement with investigations of Novruzova (1968) and Carlquist (1970) shorter vessel elements and a lower number of bars per perforation are interpreted as adaptations to drier/colder conditions. Data of the soil water content (measured under the 1245 plants) and the distribution of the two morphotypes within the plantation showed that $63 \%$ of the plants grown on the drier micro-sites are of the morphotype "Grey", while $91 \%$ of the plants grown on the wetter sites are of the morphotype "Yellow" (Reissmann unpublished). In addition ongoing measurements of the xylem sap flow and the leaf water potential of the two morphotypes indicate a stronger impact of drought on the water supply of the plants of the morphotype "Yellow" compared to the plants of the morphotype "Grey". These preliminary results are in agreement with the observation that plants of the morphotype "Yellow" are more frequent at sites of lower altitude with higher precipitation (Coelho et al. 2002). In this context our observations on the wood anatomy of the two morphotypes gave evidence for a better adaptation of the "Grey"-type to drier sites. Consequently plants of the "Grey"-type showed a higher increment during the juvenile phase of growth compared to the plants of the "Yellow"-type. Drought 
stress especially during short dry periods is more likely in younger plants due to their more superficial root system compared to older plants (in short dry periods desiccation of the upper soil layer, while in deeper soil layers the water content remains relatively high).

\section{ACKNOWLEDGEMENTS}

We thank the CNPq/CAPES, Brasilia, and the German Academic Exchange Service (DAAD), Bonn for financial support. Furthermore we express our deep gratitude to Dalnei Neiverth, Ervateira Bitumirim for sample collection. The improvement of the manuscript by Prof. P. Baas and an unknown reviewer is especially appreciated.

\section{REFERENCES}

Baas, P. 1973. The wood anatomical range in Ilex (Aquifoliaceae) and its ecological and phylogenetic significance. Blumea 21: 193-259.

Baas, P. 1975. Vegetative anatomy and the affinities of Aquifoliaceae, Sphenostemon, Phelline, and Oncotheca. Blumea 22: 312-411.

Brazier, J.D. 1985. Juvenile wood. In: L. J. Kučera, Xylorama: 25-32. Birkhäuser Verlag, Basel, Boston, Stuttgart.

Britez, R. M., C. B. Reissmann, S. Athayde \& S. M. Silva. 1997. Chemical characterization of two forests on the coastal plains of the Ilha do Mel, Paraná, Brazil. In: T. Ando, Plant nutrition for sustainable food production and environment: 461-462. Kluwer Academic Publishers, Dordrecht.

Carlquist, S. 1970. Wood anatomy of Hawaiian, Macronesian, and other species of Euphorbiaceae. In: N. K. B. Robson, D. F. Cutler \& M. Gregory, New research in plant anatomy. Bot. J. Linn. Soc. 63, Suppl. 1: 181-193.

Carvalho, P.E. R. 1994. Espécies florestais brasileiras: Recomendações silviculturais, potencialidades e uso da madeira. EMBRAPA/CNPFLORESTAS, Colombo.

Coelho, G.C., J.E. A. Mariath \& E. P. Schenkel. 2002. Populational diversity on leaf morphology of maté (Ilex paraguariensis A. St-Hil., Aquifoliaceae). Brazilian Archives of Biology and Technology 45: 47-51.

Dinwoodie, J.M. 1963. Variation in tracheid length in Picea sitchensis Carr. Forest Products Special Report 16, Madison.

EMBRAPA. 1984. Levantamento de reconhecimento dos solos do Estado do Paraná. SNLS. Boletim Técnico 57. V. I e II.

Höster, H.R. \& C. Spring. 1971. Zur Bestimmung der Zellartenanteile im Holzgewebe. Mikroskopie 27: 220-225.

Leal, S., H. Pereira, M. Grabner \& R. Wimmer. 2003. Clonal and site variation of vessels in 7-yearold Eucalyptus globulus. IAWA J. 24: 185-195.

Loesener, Th. 1942. Aquifoliaceae. In: Die natürlichen Pflanzenfamilien, Ed. 2, 20b: 36-86. Engelmann, Leipzig.

Martinez, M. A.P., J.P. Pelotto \& N. Basualdo. 1997. Distribution of flavonoid aglycones in Ilex species (Aquifoliaceae). Biochemical Systematics and Ecology 25: 619-622.

Novruzova, Z. A. 1968. The water conducting system of trees and shrubs in relation to ecology. Izd. AN Azerb, Baku.

Ohbayashi, H. \& T. Shiokura 1989. Anatomical structure of fast-growing tropical tree species with differing growth rates. IAWA Bull. 10: 342-343 (Abstract).

Oliveira, Y.M. \& E. Rotta. 1995. Área de distribuição natural da erva-mate (Ilex paraguariensis St. Hil.). EMBRAPA Documentos 15: 17-35. 
Reissmann, C. B., O. Dünisch \& M. R. Boeger. 2003. Beziehung zwischen ernährungsbiologischen ( $\mathrm{Fe}, \mathrm{Mn}, \mathrm{Ca})$ und strukturellen Merkmalen ausgewählter Morphotypen der Mate-Pflanze (Ilex paraguariensis St. Hil.). In: R. F. Hüttl, Boden, Wald und Wasser: 146-171. Shaker Verlag, Aachen.

Reissmann, C. B., M.I. Radomski \& R. M. B. Quadras. 1999. Chemical composition of Ilex paraguariensis St. Hil. under different management conditions in seven localities of Paraná State. Brazilian Archives of Biology and Technology 42: 187-194.

Richter, H. G. \& M. J. Dallwitz. 2000. Commercial timbers: descriptions, illustrations, identification, and information retrieval. http://biodiversity.uno.edu/delta/

Romeis, B. 1968. Mikroskopische Technik. R. Oldenbourg Verlag, München, Wien.

Sass, U. \& D. Eckstein. 1995. The variability of vessel size in beech (Fagus sylvatica L.) and its ecophysiological interpretation. Trees 9: 247-252.

Scherer, R., P. Urfer, M. R. Mayol, L. D. Belingheri, F. Marx \& M. J. J. Janssens. 2002. Inheritance studies of caffeine and theobromine content of Mate (Ilex paraguariensis) in Misiones, Argentina. Euphytica 126: 203-210.

Valduga, E., R. S. Freitas, C.B. Reissmann \& T. Nakashima. 1997. Caracterização química da folha de Ilex paraguariensis St. Hill. (erva-mate) e de outras espécies utilizadas na adulteração do mate. CEPPA 15: 25-36.

Zampier, A.C. 2001. Avaliação dos níveis de nutrientes, cafeína e taninos em erva-mate (Ilex paraguariensis St. Hil.) após adubação e sua relação com a produtividade. Master Dissertation. Curso de Engenharia Florestal. UFPR, Curitiba.

Zobel, B. J. 1985. Juvenile wood in tropical forest plantations: its characteristics and effect on the final product. CAMCORE Bulletin on Tropical Forestry 2: 1-19.

Zobel, B. J. \& J. B. Jett. 1995. Genetics of wood production. Springer Verlag, Berlin.

Zobel, B. J. \& J.R. Sprague. 1998. Juvenile wood in forest trees. Springer Series in Wood Science, Springer Verlag, Berlin. 